\title{
A METÁFORA E A CONSTITUIÇÃO DA SUBJETIVIDADE NA PSICOSE
}

\author{
Margareth Schäffer \\ Marlene Teixeira \\ Valdir do Nascimento Flores
}

RESUMO: This paper aims to reflect on the role and relevance of metaphor in the psychotic discourse. In this way, activity verbal can be defined as a place of the manifestation of the subjective in the language. As a consequence, metaphor is not describe as a closed structure, but it is to be captured in the very process of the enunciation.

PALAVRAS-CHAVE: enunciação, psicanálise, metáfora, psicose, subjetividade.

\section{INTRODUÇÃO}

Esta investigação dá continuidade aos trabalhos desenvolvidos por Schäffer et alii (1998 e 1999) a respeito de questões relativas às marcas lingüísticas que possibilitam entender o funcionamento da linguagem na psicose. O problema de pesquisa incide sobre a construção de um referencial teórico-metodológico de análise da metáfora, em discursos de psicóticos, a partir da articulação entre a lingüística enunciativa e a psicanálise freudo-

Margareth Schäffer é professora da Faculdade de Educação da UFRGS. Marlene Teixeira é professora do Curso de Letras da UNISINOS

Valdir do Nascimento Flores é professor do Instituto de Letras da UFRGS. 
lacaniana. Com isso, busca-se, em lingüística, o reexame do estudo semântico da linguagem e, em psicanálise, instrumentos para a compreensão clínica das patologias. Em síntese, objetivamos discutir os métodos em semântica lingüística e psicanálise, tendo em vista a ampliação de análise da linguagem e a articulação epistemológica entre essas duas áreas. Os resultados daí advindos deverão trazer ganhos significativos para a lingüística, no que concerne à ampliação de seu escopo teórico e para a psicanálise, no que concerne à compreensão da clínica. Vale dizer que não faremos aqui mais do que registrar alguns pontos de contato acerca dessas questões e, especialmente, daquelas relativas à psicose.

Partindo-se disso, pode-se formular a hipótese segundo a qual a diferença entre a neurose e a psicose é de caráter estrutural e pode ser melhor abordada de um ponto de vista teórico-metodológico que considere o aspecto semântico da linguagem. Enfim, consideramos que a semântica, em lingüística, e a clínica, em psicanálise, têm seus métodos de análise substancialmente alterados, quando propostos a partir da articulação entre essas duas áreas.

O ESTUDO DA METAFORA NA PSICANALISE: METAFORA PATERNA COMO CONDIÇAO DA CONSTITUIÇAO SUBJETIVA DO SUJEITO.

Em estudo sobre o modo de funcionamento da negação nas neuroses e psicoses (cf. Schaffer et alii 1998 e 1999), verificamos que esse fenômeno lingüístico principalmente no que se refere às psicoses, não funciona de forma isolada. Ele está ligado ao acesso ou não do sujeito ao mundo simbólico que, por sua vez, tem relação com a constituição da metáfora paterna.

Por um lado, é comum encontrar na bibliografia especializada a afirmação de que, na psicose, o sujeito está excluído do simbólico (não faz "laço"), já que o recalque da função paterna não se estabeleceu na organização do saber psicótico, o que equivale a dizer que o psicótico está preso na cadeia entre o Imaginário e o Real. Por outro lado, há elementos que permitem ver nisso um engano.

Calligaris, no livro Introdução a uma clínica diferencial das psicoses (1989), referindo-se a essa questão, diz que, se o sujeito ficasse entre o Imaginário e o Real, ele nada mais seria que um "animal": se o psicótico não está referido à função paterna, nem por isso ele está tomado só entre Imaginário e Real. Mas qual a sua amarragem simbólica, que tipo de significação subjetiva pode ter? (CALLIGARIS, 1989, p.26).

O psicótico está "tomado" na estrutura da linguagem, mas, segundo 
Calligaris, está tomado apenas metonimicamente, como se estivesse "errando" pela linguagem. Na verdade, o que autor se pergunta é como essa significação se produz e se mantém, sem amarragem metafórica.

Segundo Schäffer et alii (1998) o saber psicótico é bem distinto do saber neurótico: no saber neurótico, na medida em que a função paterna é recalcada, produz-se um "buraco"; alguma coisa é simbolizada como ausência. Se há "buraco", há uma espécie de amarragem, de algo que foi simbolizado. No saber psicótico, entretanto, a função paterna falta, porque foracluída. Nas palavras de Calligaris, estaria faltando alguma coisa da ordem do pai, enquanto não simbolizado.

Ora, é esse "não simbolizado" que tem causado algumas confusões. O que exatamente não foi simbolizado? Se algo não foi simbolizado é porque não há significantes? Estes foram forcluídos? Citando na íntegra a posição de Calligaris a esse respeito, temos:

É importante considerar que o que está forcluído não são os significantes relativos ao pai, ao quadro edípico, mas o que está forcluído é a função organizadora do nome-do-pai. O que está forcluído é a amarragem enquanto tal. Não é que o paciente psicótico não disponha de significantes para falar de seu pai, de sua família. O problema é que esses significantes não têm a função de amarragem central como numa metáfora neurótica (CALLIGARIS, 1989, p.44).

Parece que é possível dizermos que se trata, pois, da foraclusão de uma função. Assim, a função é que vai falar no Real, porque não foi simbolizada. O que vai produzir-se no Real, por exemplo, sob forma de alucinação, é a função paterna (CALLIGARIS, 1989, p.44). Dito de outra forma: se há foraclusão do Nome-do-Pai para um psicótico, isso não significa que não haja uma certa história edípica. Para Calligaris, o problema do psicótico é que, nessa história edípica, não houve produção de uma metáfora do tipo neurótico. Assim, não é possível dizer, como fazem alguns autores, que os significantes foram foracluídos. Os significantes dessa história (significantes paternos) fazem parte do saber do sujeito; o que não foi simbolizado é a função central desses significantes (Idem, p. 44). Para Calligaris, essa função corresponde à "amarragem" dos significantes ${ }^{1}$.

Assim, uma função é foracluída, mas não os significantes edípicos e paternos. Se é a função que está em xeque, então podemos dizer que os

\footnotetext{
1 "Se existe uma significação no sujeito psicótico fora da crise, então deve haver uma metáfora, uma metáfora diferente da metáfora paterna, sem uma amarragem fixa, porque, se há amarragem fixa, há função paterna. Qualquer metáfora delirante é paterna. Uma metáfora delirante responde à necessidade, para o sujeito psicótico, de estruturar-se como o neurótico" (CALLIGARIS, 1989, p.45)
} 
significantes estão organizados de outra forma. O saber é acessível ao sujeito, mas não a organização de tal saber em torno de uma função. $\mathrm{O}$ psicótico pode produzir, então, uma metáfora delirante, só que o agente dessa metáfora está no Real, e não no Simbólico. O sujeito organiza uma metáfora (delirante) ao redor de um pólo central (não simbolizado) que está no registro do Real .

O que não foi simbolizado é uma função de organização dos significantes. Como resultado dessa desorganização - da "ausência" de um significante de base que é resultante da constituição da metáfora paterna temos "distúrbios" muito graves de linguagem. Há um fracasso radical da metáfora lingüística, sem que esses distúrbios contaminem totalmente a linguagem do sujeito.

Em suma, os casos por nós analisados em torno do funcionamento da (de)negação, em Schäffer et alii (1998), se caracterizam como negação do não, ausência do não, ou seja, como psicose. Essa ausência, na opinião da autora, estaria ligada ao Simbólico, motivo pelo qual Lacan teria situado o fundamento da psicose no nível de um fenômeno de foraclusão do Nomedo-Pai, ou em outros termos, no não estabelecimento da metáfora paterna.

Parece, então, que a falha na função de organização dos significantes está ligada ao estabelecimento do símbolo não e, por conseqüência, o sujeito não consegue simbolizar o Real, ou seja, não consegue estruturar o Real. Assim, ao invés de o sujeito realizar uma metáfora do tipo lingüístico, tal como aparece nas neuroses, ele, por estar referido diretamente ao Real, elabora, nesse mesmo Real, uma metáfora do tipo delirante. Enfim, faz-se necessário entendermos como acontece a estruturação subjetiva do sujeito, dependente que é do estabelecimento da metáfora paterna e da negação. Isso justifica a necessidade do estudo da metáfora na psicose.

\section{A METAFORA NA PSICANÁLISE}

Em psicanálise, encontramos o estudo da metáfora associado ao da metonímia e este, por sua vez, ligado às noções de condensação e deslocamento, tal como estabelecidas por Freud. Deter-nos-emos, aqui, no modo como Lacan se apropria das formulações freudianas acerca da metáfora e as eleva a um conceito fundamental para designar a relação do sujeito com a linguagem. Nos Escritos (1998), Lacan considera que a metáfora se situa no ponto preciso em que o sentido se produz a partir do não-senso. Já no Seminário 3 sobre as psicoses (1985) Lacan afirma que a carência do significante paterno - foraclusão da metáfora paterna engendrará uma metáfora que não se estrutura na metonímia. Assim, o 
grande Outro é esvaziado de sua função simbólica e não mais funciona da mesma maneira que na neurose.

Para Lacan, a metáfora paterna tem o funcionamento prototípico da metáfora. O sentido se acha inscrito nessa metáfora fundadora - metáfora paterna -, a qual precede toda e qualquer metáfora realizada linguisticamente. É por meio dessa metáfora fundadora que o sujeito acessa ao simbólico e constitui-se como sujeito desejante.

De acordo com os trabalhos de Schäffer et alii (1998 e 1999), os sujeitos psicóticos não conseguem acessar ao mundo simbólico de forma adequada - não amarragem simbólica -, e isso é perceptível na forma linguageira utilizada por eles: ausência de uso da negação no sentido (de)negatório e presença de metáforas caracterizadas como sendo do tipo delirante, segundo terminologia utilizada por Calligaris.

Tais fenômenos parecem ter sua origem justamente no fato que se caracteriza como foraclusão da metáfora paterna, tal como delimitada por Lacan. As perguntas que podem ser formuladas aqui em decorrência desse raciocínio são: qual a ligação que existe entre a ausência de tal metáfora, que precede todas as outras, com o uso de metáforas "delirantes" pelo psicótico? Qual seria a diferença, em termos lingüísticos, do uso da metáfora na neurose, com o uso da metáfora "delirante" pelo sujeito na psicose?

Se a metáfora primordial não pôde se estabelecer adequadamente, parece conseqüente supor que haverá comprometimento no uso da metáfora lingüística. Segundo Lacan, a metáfora se caracteriza por uma substituição significante, ou seja, uma palavra funciona pela outra, havendo supremacia do significante em relação ao significado. Ora, para fazer tal deslocamento significante, é necessário que o próprio sujeito esteja implicado na metáfora. Assim, a metáfora condensa em si a função mesma do sujeito em sua luta com as palavras - cabe a ele inventar-lhe suas letras (KAUFMANN, 1996, p.333). Podemos ver, então, que a elaboração da metáfora lingüística depende da implicação do sujeito desejante e este, para acessar a esse estatuto, deverá ter passado pelo processo de elaboração da metáfora paterna. Em termos lingüísticos, a metáfora constitui-se como um mecanismo de linguagem que intervém ao longo do eixo sincrônico/ paradigmático.

Face a essas considerações, ficam algumas questões: o que Lacan quer dizer com o uso do termo "metáfora paterna"? Qual a diferença entre essa e as metáforas do tipo lingüístico? Para responder à primeira questão, recorreremos aos estudos de Lacan, mais precisamente aos Escritos, ao Seminário 5: as formações do inconsciente e ao Seminário 3 sobre as psicoses, sendo que é nesse último que Lacan introduz as primeiras referências explícitas sobre a metáfora. Já para responder a segunda questão, recorreremos, logo a seguir, às reflexãos de Ducrot acerca do sentido na 
enunciação.

\section{A METAFORA NAS NEUROSES E NAS PSICOSES}

Calligaris (1989) situa o essencial da diferença entre psicose e neurose no fato de que a metáfora neurótica é paterna e de que a "metáfora psicótica" seria sem agente suposto. Lendo o texto de Lacan Uma questão preliminar a todo tratamento possível da psicose (Escritos, 1998), percebemos que a especificidade das psicoses em relação às neuroses reside na foraclusão do Nome-do-Pai ou, em outros termos, no não estabelecimento da metáfora de todas as metáforas - a metáfora paterna. Vemos, assim, a psicose sendo denominada por aquilo que lhe falta, por uma ausência - a ausência de amarragem dos significantes, dada por um significante primordial/central, o paterno. Para Calligaris, tal ausência está na origem da constituição do delírio que provém após uma crise psicótica e esse delírio é uma metáfora: uma metáfora delirante, na medida mesma em que é uma metáfora fracassada (CALLIGARIS, 1989, p.22).

O psicótico não dispõe da referência paterna, ao passo que o neurótico dispõe e essa é causa de sua filiação como sujeito desejante. Por não haver referência possível à metáfora paterna, já que ela não foi simbolizada pelo psicótico, o lugar de amarragem dos significantes não pode retornar no Simbólico, mas somente no próprio Real. A função paterna, não simbolizada, retorna no Real: é o delírio, onde o psicótico se vê às voltas com a organização de uma metáfora no Real, já que foi nesse lugar que a função paterna pôde se organizar.

Entretanto, se o psicótico não simbolizou a função paterna, isso não quer dizer que o universo simbólico não exista e que o sujeito esteja tomado somente entre o Imaginário e o Real. Para Calligaris, a evidência é que existe significação no sujeito psicótico, mas como esta significação se produz e se mantém eventualmente sem amarragem metafórica fixa é o que não se sabe (CALLIGARIS, 1989, p.26). Se houvesse a possibilidade de alguma amarragem central para todos os psicóticos, esses seriam neuróticos, já que nestes há a possibilidade de uma amarragem paterna fixa. Essa amarragem é o que permite, conforme Calligaris, um universal positivo da neurose, enquanto a psicose não tem estatuto próprio, definida que é pela ausência.

Porém, a tentativa de constituição de uma metáfora do tipo delirante após o desencadeamento de um crise psicótica, parece aproximarse da estruturação positiva. Para Lacan, o caminho percorrido pelo sujeito psicótico para estruturar uma metáfora delirante é um momento importante de socialização - uma espécie de simbolização precária organiza-se aí. 
Calligaris, em face a essas considerações de Lacan, pergunta-se como pode o psicótico construir uma metáfora delirante, análoga à metáfora neurótica, isto é, uma amarragem central que possa distribuir todas as significações subjetivas, mas que vai ser delirante (CALLIGARIS, 1989, p.37). Salienta ainda que esta não é considerada delirante por ser inverossímil e, sim, por uma razão estrutural, pois o lugar central dessa amarragem não está simbolizado, porque é algo que não estava no saber do sujeito.

A questão que se coloca nesse momento é: como podemos distinguir, linguisticamente, a metáfora do tipo neurótico da metáfora do tipo delirante do psicótico? A resposta a essa questão certamente trará significativos avanços para o diagnóstico clínico das patologias e, por conseqüência, para o seu tratamento. Tais avanços decorrentes dessa precisão devem-se, principalmente, ao fato de ser a constituição de uma metáfora delirante a saída da crise.

A constituição do delírio é uma tentativa do sujeito de construir uma metáfora paterna, mesmo que essa seja delirante. Por mais intolerável que seja para o analista suportar a constituição desse delírio, parece que ele não pode furtar-se a trabalhar com ele. A via terapêutica mais comum a psiquiátrica principalmente - parece escolher seu caminho pela via de uma inibição farmacológica ou terapêutica do delírio. Em outras palavras, onde justamente deveria haver um investimento, há um silenciamento, seja por uma via ou pela outra.

No próximo item, procuraremos discutir, com mais detalhamento, o modo como a ausência da metáfora paterna está ligada aos fenômenos de foraclusão do Nome-do-Pai e de recusa da castração simbólica (renegação).

\section{A FORACLUSAOO DO NOME-DO-PAI}

Na origem da constituição subjetiva do sujeito vemos perfilar-se a noção de recusa (renegação) como um mecanismo de defesa em face da realidade externa. $\mathrm{Na}$ especificidade da constituição subjetiva psicótica, o sujeito, e isso já na visão de Freud, extrai sua força de convicção de uma parte da verdade histórica, que vem a se colocar no lugar em que a realidade é repelida. Esse processo se esclarece pela articulação da recusa com a falta de metáfora paterna, ou seja, a lei do pai, que repousa na castração simbólica, não encontra lugar, já que o desejo materno ocupa todo o espaço. Para Lacan, o psicótico é confrontado com uma ausência de significante que deveria advir pelo lado do Nome-do-Pai: a foraclusão do Nome-doPai encontra-se pois em paralelo com a recusa (renegação).

O sujeito, por não se submeter à castração simbólica, compromete todo o processo de recalcamento e, conseqüentemente, sua própria estruturação como desejante. $\mathrm{O}$ recalcamento primordial é malogrado e, por derivação, cada significante metafórico, cada metáfora que poderia 
advir após a instauração da metáfora paterna, também malogram. A metáfora paterna do Nome-do-Pai é o grande referente. Em outras palavras, as metáforas somente são possíveis graças a esse recalcamento originário.

Melman, ao comentar a especificidade das metáforas delirantes, cita dois casos de psicose, onde a ausência de recalcamento é explícita, diz ele: ...o que surpreendia nas conversas (...) era que tratava-se de conversas livres de todo recalcamento, e igualmente de toda reticência e (de)negação (MELMAN, 1991, p.53). O que se depreendia das palavras das duas pacientes era, segundo Melman, esse sentimento de acesso possível ao Real, como se esse Real nada mais guardasse de impossível (Idem). O "isso" falava abertamente, sem interdições - falavam como pensavam, nos diz Melman. Esse inconsciente a "céu aberto" é explicado pelo não acesso à lei do pai.

O pai só se faz presente por sua lei que é fala, e é só na medida em que sua fala é reconhecida pela mãe que ela assume valor de lei. Nesse sentido, se a posição for contestada e o filho permanecer assujeitado à mãe, o sujeito fica foracluído da metáfora paterna. Não há interdições, não há lei, não há aceitação da castração simbólica - o "isso" fala abertamente, como nos dois casos citados acima. O advento do Nome-do-Pai, em substituição ao desejo de ser o falo da mãe, é impossibilitado e o sujeito não entra realmente no édipo. A estruturação da subjetividade é "mal executada", já que a contribuição decisiva do édipo - inserir o sujeito na lei -, falha, a castração simbólica falha, a negação falha.

\section{A METAFORA PATERNA E A FORACLUSAOO}

A questão que se coloca, de início, é sabermos de que maneira o sujeito renuncia a ser o falo para se tornar sujeito do desejo. O édipo é o eixo fundamental para se obter uma resposta.

Lacan nos apresenta essa metáfora no seu aspecto mais formal da seguinte forma:

\begin{tabular}{|c|c|c|c|}
\hline Nome-do-Pai & Desejo da Mãe & A & \\
\hline $\begin{array}{r}\text { Desejo da Mãe } \\
\text { sujeit }\end{array}$ & Significado do & Falo & (Lacan, 1998, p.563) \\
\hline
\end{tabular}

A conseqüência dessa metáfora é que o sujeito deixa de se confundir com o objeto de desejo que ele inspira imaginariamente,

${ }^{2} \mathrm{O}$ termo foraclusão foi proposto por Lacan para traduzir o vocábulo alemão verwerfung utilizado por Freud. O conceito de foraclusão é uma construção teórica que tenta explicar o mecanismo psíquico na origem da psicose. Na origem desse acontecimento foraclusivo, encontramos uma desordem na simbolização da experiência de castração. Essa falta de simbolização se traduz, no psicótico, por uma incerteza quanto a sua identidade sexual e por uma "perda" do sentido da realidade. 
acessando ele próprio ao desejo, segundo a ordem prescrita pela lei. Quando a metáfora do Nome-do-Pai não se produz, ou seja, o édipo não se instaura na sua plenitude e o sujeito permanece bloqueado em sua posição primeira de falo materno imaginário, advém a psicose.

Sabemos que na neurose o significante é recalcado no inconsciente, mas na psicose este é foracluído e rejeitado para fora dele, o que corresponde ao verworfen da terminologia freudiana. Entretanto, esse significante, inacessível para o sujeito, não desaparece simplesmente - ele reaparece no Real sob a forma alucinatória. Tal aparecimento deve-se à falta de metáfora simbólica, ou seja:

No ponto em que o Nome-do-Pai é invocado, pode então responder no Outro um puro e simples buraco, o qual, pela carência do efeito metafórico, provoca um buraco correspondente no lugar da significação fálica (Lacan; 1998, p.558).

O ressurgimento alucinatório do significante foracluído da castração é que produz o delírio. Lacan situa na foraclusão do Nome-doPai, no lugar do Outro e no malogro da metáfora paterna a falha que confere à psicose sua condição essencial. Assim, para que se desencadeie a psicose, é preciso que o Nome-do-Pai, foracluído, ou seja, nunca advindo no lugar do Outro, seja chamado ali em oposição simbólica ao sujeito (Lacan, 1998, p.584). As conseqüências provocadas pela foraclusão do significante do Nome-do-Pai são consideradas por Lacan como um buraco cavado no campo do significante, e é em torno desse que vai se construir uma nova realidade - a realidade do psicótico, somente dele.

Finalmente, para Lacan, a metáfora do Nome-do-Pai apresenta múltiplas conseqüências, quer em termos do seu fracasso, instalando os processos psicóticos, quer em termos de seu sucesso, como algo que, segundo Jöel Dor (1989), aliena o desejo do sujeito na dimensão da linguagem ao instituir uma estrutura de divisão subjetiva (Spaltung) que o separa irreversivelmente de si mesmo (DOR, 1989, p.94-95). São as conseqüências que concernem ao fracasso da função estruturante da metáfora paterna que nos interessam neste texto, principalmente, porque, em termos clínicos, a foraclusão apresenta-se como um critério metapsicológico operatório na discriminação dos processos psicóticos.

Em suma, a foraclusão do Nome-do-Pai que neutraliza o advento do recalque imaginário provoca ao mesmo tempo o fracasso da metáfora paterna e compromete gravemente para o sujeito o acesso ao simbólico, na justa medida em que este permanece cativo da relação dual imaginária com a mãe. E é esse acesso ao Simbólico (ou não), nas suas diversas manifestações significantes, que nos interessa fundamentalmente, ou seja: 
são os significantes primordiais, significantes que se prestarão a possibilidades de substituição metafórica que são objeto de interesse aqui. Interessa-nos destacar, ainda, por conseqüência do fenômeno foraclusivo, as confusões entre significante e significado que o psicótico apresenta, já que estas atestam o fracasso da metáfora lingüística.

Entretanto, este último tópico requer um tratamento especial, ou seja, trata-se do estudo do significante, tanto em termos da psicanálise como em termos da lingüística, o que requer uma análise mais acurada e aprofundada, questão esta que excede os propósitos deste texto.

Cabe, neste momento, apenas acentuar algumas questões teóricas concernentes ao estudo das metáforas na teoria psicanalítica. São estas questões que demarcam com mais clareza a necessidade de uma análise lingüística do fenômeno metafórico.

DA PSICANALISE A LINGÜÍSTICA: ALGUNS ELEMENTOS DE INTERMEDIAÇAO

Lacan, no Seminário 5: as formações do inconsciente (1999), fala de um jogo significante da metonímia e da metáfora, relacionando-as às relações sintagmáticas e paradigmáticas, respectivamente. Situa-as, ainda, em relação à função do significante no inconsciente e, relembrando Jakobson, salienta que há um grupo mínimo de significantes que se faz necessário para que sejam dadas as condições elementares da análise lingüística. Diz, também, que [a lingüística] tem a mais estreita relação com a psicanálise pura e simples. Elas chegam a se confundir. Se examinarmos de perto, veremos que não são essencialmente diferentes uma da outra (Lacan 1999, p.14). Finalmente, retoma algumas considerações por ele realizadas no seminário sobre as psicoses (Seminário 3), salientando que a psicose é fundamentada numa carência significante primordial. Em outros termos, Lacan nos fala do efeito de total estranheza do Real que se produz nos momentos de ruptura, desse diálogo do delírio que é o único pelo qual o psicótico pode sustentar em si o que chamaremos de uma certa intransitividade do sujeito (Idem).

Vemos, assim, que não há como deixar de considerar as relações entre o significante e suas funções essenciais, que são a metáfora e a metonímia. Vejamos o que diz Lacan a este respeito: ...daquilo que chamo funções essenciais do significante, na medida em que é por elas que o arado do significante sulca no real o significado, literalmente o evoca, o faz surgir, maneja-o, engendra-o . Trata-se das funções da metáfora e da metonímia (Idem, p.33). Estas são funções criadoras que o significante exerce sobre o significado, o que significa dizer, no que concerne ao papel 
da metáfora, que não existe sentido senão metafórico, só surgindo o sentido da substituição de um significante por outro significante na cadeia simbólica (idem, p.16). E é nesta relação de substituição que reside o recurso criador, a força criadora da metáfora:

A metáfora é uma função absolutamente genérica. Eu diria até que é pela possibilidade de substituição que se concebe o engendramento, por assim dizer, do mundo do sentido. Temos de apreender toda a história da língua, isto é, das mudanças de função graças às quais uma língua se constitui, aí, e não em outro lugar. [...] é por intermédio da metáfora, pelo jogo de substituição de um significante por outro num lugar determinado, que se cria a possibilidade não apenas de desenvolvimentos do significante, mas também de surgimentos de sentido sempre novos, que vêm sempre contribuir para aprimorar, complicar, aprofundar, dar sentido de profundidade àquilo que, no real, não passa de pura opacidade (Idem, p.35).

Nesta longa citação, verificamos, de forma concisa, que Lacan atribui à metáfora uma função geradora de sentidos novos. Em outras palavras, Lacan assinala, veementemente, que a metáfora não é uma injeção de sentido, rejeitando, assim, a tese que defende que há um reservatório de sentidos disponíveis em algum lugar. De certa forma, é a tese sobre a existência de um sentido literal que está sendo rejeitada.

Conclui-se, então, que a via metafórica preside não apenas a criação e a evolução da língua, mas também a criação e a evolução de sentido como tal, quer dizer, do sentido na medida em que algo não apenas é percebido, mas no qual o sujeito se inclui, ou seja, na medida em que o sentido enriquece a nossa vida (Idem, p.37).

O jogo de substituição significante que preside o ato da metáfora não pode ser confundido com a metáfora propriamente dita, ou seja, a substituição significante não é a metáfora; a substituição é a articulação, o meio significante, onde se instaura o ato da metáfora (Idem, p.43). Lacan faz questão de assinalar tal distinção, de forma que não se faça abusos de linguagem. Assim, dizer que a metáfora produz-se no nível da substituição significa que a substituição é uma possibilidade de articulação do significante, que a metáfora exerce sua função de criação de significado no lugar onde a substituição pode se produzir, mas isso são duas coisas diferentes. Do mesmo modo, a metonímia e a combinação são duas coisas diferentes (Idem, p.43-44).

Entretanto, apesar de serem duas coisas distintas, toda vez que há substituição, há efeito ou indução metafórica, lembra Lacan. 
Ao ligar a economia do que está gravado no inconsciente à combinação significante, Lacan reconduz a discussão à origem da linguagem, afirmando que temos que considerar todas as significações humanas como tendo sido, em algum momento, metaforicamente geradas por conjunções significantes (Idem, p.58). De certa forma, ele considera que a própria língua, no seu processo constitutivo, é metafórica e, assim, Lacan desfaz a idéia de um sentido primeiro, originário. Em termos lingüísticos, tal concepção é, no mínimo, problemática. Voltaremos a esta questão na próxima seção.

No que diz respeito ao sucesso/insucesso da criação metafórica, Lacan faz as seguintes considerações: a metáfora é bem sucedida quando há uma mudança de sentido, ou seja, quando o sentido de algo torna-se um novo sentido - a criação desse sentido é a finalidade do funcionamento da metáfora (Idem, p.63); o insucesso é chamado de tentativa de uma criação metafórica, ou seja, alguma coisa não foi criada e os efeitos dessa metáfora mal sucedida devem ser inscritos no esquema no nível do objeto metonímico.

Ao sublinhar o funcionamento da metáfora e da metonímia na formação do inconsciente, de uma forma geral, Lacan está tratando da estrutura da fala, ou seja, para ele, há uma medida comum entre o inconsciente e a estrutura da fala, enquanto comandada pelas leis do significante. A medida comum, em uma formulação mais rigorosa, diz respeito às formas metafóricas e metonímicas. Entretanto, cabe perguntar, especificamente no que diz respeito à metáfora, como se dá essa criação de sentidos no discurso, na estrutura da fala do psicótico.

A questão que se coloca a propósito das psicoses é saber o que acontece com o processo de comunicação quando, justamente, ele não chega a ser constitutivo para o sujeito. Lacan parte do princípio de que não há sujeito se não houver um significante fundante, o qual, por sua vez, diz respeito à constituição, pelo sujeito, da metáfora paterna: o pai acha-se numa posição metafórica, na medida e unicamente na medida em que a mãe faz dele aquele que sanciona, por sua presença, a existência como tal do lugar da lei (Idem, p.202). Na psicose, o Nome-do-Pai, o pai como função simbólica, o pai no nível entre mensagem e código e código e mensagem é verworfen. O pai não intervém como lei, não é integrado à vida do sujeito, o que ocasiona uma dissociação entre mensagem e código: as mensagens são puras ou interrompidas.

Relembrando o que nos diz Lacan sobre o ato metafórico - um significante que surge no lugar de outro significante - e relembrando o que ele nos diz sobre o pai - o pai é uma metáfora - temos, então, que o pai é um significante que substitui outro significante. Nisso está o essencial da 
intervenção do pai no complexo de édipo: é na medida em que o pai substitui a mãe como significante que vem a se produzir o resultado comum da metáfora (Idem, p.181).

O que é rejeitado do Simbólico reaparece no Real. Esse Real de que se trata aqui, é a alucinação, isto é, o Outro enquanto falante. Para o psicótico, é o Outro que fala com ele. No nível do discurso, isso aparece como decorrente de um código de mensagens sobre o código, ou seja, uma série de mensagens que não visam senão aquilo que, no código, relacionase com a mensagem. As partículas, os pronomes pessoais, os verbos auxiliares designam o lugar do mensageiro (Idem, p.493).

As questões que estão contidas nas reflexões feitas até o momento são encaminhadas à lingüística, já que é ela, tradicionalmente, que tem refletido sobre as questões de significante/significado, metáfora/metonímia e sentido, entre outras. São interrogações que somente o entrelaçamento da lingüística com a psicanálise pode, talvez deslindar. É o que trataremos no próximo item.

\section{DA PSICANALISE A LINGÜISTICA: ALGUMAS CONSIDERAÇÕES} SOBRE A METAFORA

O propósito deste item é discutir questões gerais sobre o funcionamento lingüístico da metáfora, tomando por base a teoria enunciativo-argumentativa de Oswald Ducrot. Tal encaminhamento faz-se necessário, porque responde ao objetivo de estudar a articulação entre lingüística e psicanálise no estudo da construção da subjetividade, em discursos de psicóticos.

Pensar a metáfora, da perspectiva de uma teoria enunciativoargumentativa, é uma tarefa difícil e temerária em função das características da teoria de Ducrot e, principalmente, em função das noções de significação/ sentido por ele mobilizadas, as quais rejeitam a acepção clássica de sentido literal.

Ora, o conceito de metáfora é facilmente encontrado em textos de lingüística, de filosofia e de literatura, e parece ser comum a todas essas áreas concebê-lo sempre a partir da consideração de uma idéia, mesmo que às vezes vaga, de sentido literal. Nessa linha, estão as interpretações de Jakobson, Dubois, Todorov, entre outros. Vale lembrar, porém, que se a noção de sentido literal é estranha, e até mesmo contraditória, à psicanálise, Lacan recorre à teorização lingüística feita por Jakobson sobre a metáfora e a metonímia para reinterpretar os processos de deslocamento e condensação na linguagem onírica. Isso nos leva a crer, mais uma vez, que as dificuldades encontradas, quando proporcionamos o diálogo entre a 
lingüística e a psicanálise, podem ser contornadas em prol de uma análise mais ampla.

Assim, consideramos a recusa do sentido literal um eixo teórico comum a Lacan e a Ducrot, e é a partir desse eixo que procuramos estabelecer um diálogo interdisciplinar. O caminho que estamos sugerindo impele a retomada da interpretação lacaniana da noção de metáfora, oriunda da lingüística para, enfim, tratá-la articulada ao quadro da teoria enunciativa.

\section{A metáfora e a metonímia como duas vertentes geradoras de significa- do: interlocuções entre a psicanálise e a lingüística}

Apesar de reconhecer o primado do significante sobre o sujeito, vendo-o não mais como um suporte de significado, mas como portador de semanticidade, Lacan não elimina de sua teoria o significado. No Seminário 1, ele diz: o fundamento da estrutura da linguagem é o significante e o significado (Lacan, 1979, p. 300). Apenas ocorre que o significado, em sua perspectiva, pertence a uma categoria diversa do significante.

Para dar conta da significação, Lacan recorre à teoria lingüística, revendo o estudo de Jakobson (1995) sobre os processos metafórico e metonímico, através dos quais ele redimensiona as noções freudianas de condensação e deslocamento.

Estamos acostumados a procurar o significado no que é dito. Lacan propõe que o procuremos no que é não-dito, pois a linguagem é um logro, embora seja nesse logro que se fundamente a verificação da verdade.

A palavra institui - se como tal na estrutura do mundo semântico que é o da linguagem. A palavra não tem um único sentido, o termo um único emprego. Toda palavra tem sempre um maisalém, sustenta muitas funções, envolve muitos sentidos. Atrás do que diz um discurso, há o que ele quer dizer, há ainda um outro querer-dizer, e nada será nunca esgotado (Lacan, 1979, p. 275).

$\mathrm{O}$ fato de não haver univocidade do signo não quer dizer que não haja possibilidade de circunscrever a significação daquilo que é dito. $\mathrm{O}$ que é significante é o arranjo dos termos de uma ausência de algo que poderia estar lá.

Lacan chama ponto de estofo a espiral recorrente pela qual se apreende a significação. O ponto de estofo age entre os significantes, juntando as partes para formar um todo em que a significação acabará por aparecer.

O significante só deve ser considerado pelo seu valor de significante. Somente as correlações do significante ao significante lhes 
dão o padrão de toda busca de significação (Idem, p.505). De onde Lacan conclui que é na cadeia significante que o sentido insiste; embora nenhum dos elementos da cadeia consista na significação (Idem, p.506). A estrutura da cadeia significante - anéis formando um colar quase enlaça no anel de um outro colar feito de anéis (Idem, p.505) - descobre a possibilidade que temos de nos servir dela para significar algo totalmente diferente do que ela diz.

Para demonstrar que é na cadeia significante que o sentido insiste, Lacan cita um verso de Paul Valéry:

"Não ! diz a Árvore, ela diz: Não ! no cintilar

De sua cabeça soberba"

(apud Lacan, 1998, p. 507)

A significação que se depreende desse verso é a de majestade personificada em árvore. Nenhuma parte da frase detém em si a significação. Somente o deslizamento do significante majestade sob o significado árvore pôde dar o padrão da busca significação. Toda a cadeia significante se honra em cingir sua significação (Lacan, 1978, p.301).

Os efeitos de linguagem, surgidos na cadeia significante através do ponto de estofo, são determinados pelas leis de condensação e deslocamento, que Lacan aproxima dos processos metafórico e metonímico de Jakobson.

Segundo o autor, a palavra recalcada emerge no consciente através dos processos lingüísticos de metáfora e metonímia, semelhantes aos que Freud, no estudo dos sonhos, denomina mecanismos de condensação e deslocamento, respectivamente.

A condensação é um mecanismo pelo qual o conteúdo latente do sonho é transformado em conteúdo manifesto e que consiste na abreviação de uma série de processos psíquicos que se estão desenrolando no inconsciente de modo que a significação só se torna possível a partir da análise.

O deslocamento é o mecanismo pelo qual a carga afetiva liberada durante o sonho não recai sobre seu verdadeiro objeto, mas desvia sua direção e vai recair sobre um objeto secundário, aparentemente insignificante.

Jakobson (1995, p. 34-72), estudando a afasia como um problema lingüístico resultante da dificuldade de compor por similaridade ou por contigüidade, coloca a metáfora e a metonímia não mais como figuras de linguagem, mas como leis de estruturação do próprio discurso.

Partindo das colocações de Freud e Jakobson, Lacan examina os processos metafórico e metonímico, no artigo $A$ instância da letra no inconsciente ou a razão desde Freud dos Escritos (1998, p.493-533), como 
vertentes geradoras da significação.

O procedimento metafórico consiste na aproximação de dois termos de semas, que adquirem propriedades que não valem senão pela sua intercessão. Em outras palavras, esses dois termos, à primeira vista distantes, são aproximados. $\mathrm{O}$ terceiro termo não é o primeiro nem o segundo, mas tem características próprias, podendo evocar coisas não cobertas pelo primeiro ou pelo segundo termos. Um novo sentido surge numa relação de substituição de significantes que apresentam entre si uma relação de similaridade.

Por exemplo: "O amor é um seixo rindo ao sol". O primeiro termo é "O amor" e o segundo, "seixo rindo ao sol". O código lingüístico não prevê a substituição de "amor" por "pedrinhas rindo ao sol". A relação entre os dois termos é imprevisível. O contexto geral é que faz surgir o sentido (Lacan, 1998, p. 512 ). Uma palavra pela outra, eis a fórmula da metáfora (Idem, p. 510).

A metonímia baseia-se na substituição de significantes que têm entre si relação de contigüidade. Em "trinta velas por trinta barcos", o significante "barco" foi eliminado, deslizando em "velas" que passou a representá-lo. A parte toma o lugar do todo, mas dele permanece independente não formando um conjunto. A significação surge em razão da conexão imediata do pensamento entre os dois significantes em jogo (Lacan, 1998, 509).

A metonímia é sempre um não-sentido aparente. É necessário que se efetue no espírito as relações indispensáveis à sua compreensão. A conexão do navio e da vela não está em outro lugar senão no significante. É na palavra por palavra dessa relação que se apóia a metonímia (Lacan, 1998, 509).

Reunindo, em algumas frases, os termos principais do pensamento lacaniano sobre a significação temos que: a linguagem se faz consciente através das estruturações metafórica e metonímica. A significação, inacessível ao sujeito consciente, passa entre o significante enigmático e o termo que ele vem substituir. A chave dessas estruturações se encontra no inconsciente. Aquele que fala não sabe aquilo que diz, pois a verdade só é evocada como presença em lugar diverso daquele que se pretende que estivesse. Esse mistério de duas faces se liga ao fato de que

a verdade não se evoca senão nessa dimensão de álibi pela qual todo "realismo" na criação toma sua virtude da metonímia, assim como ao fato de que o sentido não liberta seu acesso senão à dupla cauda da metáfora, quando se possui sua chave única: o $\mathrm{S}$ e o s do algoritmo saussuriano não está no mesmo plano, e o homem se enganaria ao se crer situado em seu eixo 
comum que não está em parte alguma. Isso é pelo menos até que Freud tivesse feito sua descoberta. Porque se o que Freud descobriu não é isso mesmo, então não é nada (Lacan, 1998, p.521-522).

A partir dessas considerações acerca da metáfora e da metonímia, bem como a partir das questões já tematizadas precedentemente, temos, pois, o ponto de partida para uma tentativa de elaboração de certas questões entre a lingüística e a psicanálise:

1) Lacan tomou bastante livremente as conceituações de Jakobson sobre a retórica;

2) não se pode, como muitos o fazem, colocar em relação de identidade Saussure e a versão jakobsoniana de Saussure, para tomar como objeto de estudo, por exemplo, os eixos sintagmático e paradigmático, em suas relações com a metonímia e a metáfora, respectivamente;

3) porém, mesmo que possa parecer formalmente vaga a definição lacaniana sobre a metáfora paterna, sua definição de metáfora como "substituição significante com criação de sentido", assim como a definição da metonímia, bem como seu exemplo, podem servir de ponto de partida para elaborações posteriores entre a lingüística e a psicanálise.

Talvez não devamos permanecer, sob a influência de Jakobson, na idéia genérica de uma pretensa redução da retórica como um todo às formulações deste lingüista sobre a metáfora e a metonímia. O próprio Lacan, em Instância da Letra no Inconsciente ou a razão desde Freud, ao se referir aos mecanismos do inconsciente, diz:

A perífrase, o hipérbato, a elipse, a suspensão, a antecipação, a retratação, a denegação, a digressão e a ironia são as figuras de estilo (as figurae sentenciarum de Quintiliano), e a catacrese, a litotes, a antonomásia e a hipotipose são os tropos cujos termos se impõe à pena como os mais adequados para rotular esses mecanismos (Lacan, 1998, p.525).

Como ocorre com muita freqüência, Lacan é sumário nessas afirmações, e raramente retorna a algum assunto, para explicar como chegou às suas conclusões. Entretanto, abre-se para nós um caminho, o de tentar dar conta dos mecanismos do inconsciente, na heterogeneidade da fala, recorrendo às tradições lingüística e retórica, de uma maneira que deve se pretender articulada.

Recorrendo, especificamente, à tradição lingüística, apresentamos as considerações que seguem em termos de encaminhamentos. 


\section{O SENTIDO, A LÍNGUA, A ENUNCIAÇAO}

Nossa intenção, aqui, é indicar uma possibilidade de estudo do sentido, tomando por base algumas considerações advindas da teoria enunciativa de Ducrot. Vale, no entanto, lembrar que não objetivamos apresentar um modelo "ideal" de análise da língua o qual possibilitaria o estudo da metáfora, de um ponto de vista lingüístico, na psicose. Nosso propósito é apenas buscar na lingüística - e neste caso trata-se da lingüística que enfoca os fenômenos de enunciação - elementos que possibilitem a formulação de uma concepção de sentido na linguagem que seja articulável à problemática da psicose.

Optamos pela teoria de Ducrot, porque, em vários momentos de sua obra, o autor busca ratificar a tese de que a argumentação não é um componente que se acrescenta à língua, mas que a ela está ligado constitutivamente, recusando a abordagem retórica de análise da argumentação. Soma-se a isso o fato de o autor rejeitar a noção de sentido literal, ou aquilo que chama de abordagem comum do sentido. Segundo ele, ... a utilização argumentativa da língua, longe de lhe ser sobreposta, está nela inscrita, é prevista em sua organização interna (Ducrot, 1981, p.180). A tarefa de uma semântica, definida nesses termos, seria a de dar conta do valor argumentativo como nível fundamental da descrição lingüística (Ducrot, 1988, p.51).

As definições metodológicas que proporcionam corroborar essa tese são as de frase e enunciado às quais são atribuídas, respectivamente, os valores semânticos significação e sentido. Para Ducrot, frase é um objeto teórico que não pertence ao domínio do observável (Ducrot, 1987). É uma estrutura abstrata, ou seja, algo absolutamente diferente de uma seqüência de palavras escritas (Ducrot, 1989, p.14). O enunciado, ao contrário, é aquilo que o lingüista toma como sendo um observável, isto é, uma manifestação particular da frase, em uma dada situação enunciativa..

A diferença entre frase e enunciado é que a primeira não é observável e pertence à estrutura interna da língua, enquanto o segundo é um observável, entendido como a realização da frase. A esses termos Ducrot associa os valores semânticos de significação e de sentido. Entretanto, isso não deve levar a crer que o sentido é o produto de uma operação do tipo significação + situação de enunciação = sentido. A significação é o valor da frase e deve ser vista não como um sentido literal ao qual se somariam informações contextuais de ocorrência, mas como uma espécie de "roteiro" que indica o que o locutor deve fazer em uma situação específica. A significação tem um caráter instrucional. O sentido, por sua vez, é produto de uma interpretação situacional das instruções advindas da 
frase. Enfim, o sentido é a qualificação da enunciação, ou seja, o que o falante comunica através de seu enunciado é uma qualificação da enunciação desse enunciado (Ducrot, 1987, p.172). Em outras palavras, a diferença entre significação e sentido é de natureza e não de função.

A noção de enunciação é fundamental para que se entenda a passagem da frase ao enunciado. Conforme Ducrot, a enunciação não pode ser confundida com a atividade psico-fisiológica implicada na produção do enunciado, nem com o produto dessa atividade. Para ele, a enunciação é um acontecimento constituído pelo aparecimento de enunciado (Ducrot, 1987, p.168), isto é, a enunciação não é um ato de um locutor, mas uma ocorrência histórica que dá existência a algo que não existia antes: o enunciado. Fica claro, nessa concepção, o motivo para entender o sentido do enunciado como uma qualificação da enunciação. Isso dá-se em função de que é na ocorrência singular da frase (o enunciado) que o locutor a qualifica ilocutoriamente, referencialmente, etc.

Um dos objetivo de Ducrot, com a formulação de sua teoria nesses termos, é o de subverter as concepções clássicas do sentido. Não há espaço para pensar numa conotação contraposta a uma denotação. O sentido do enunciado nada mais é do que uma das múltiplas realizações da frase. A teoria da argumentação inscrita na língua tem, portanto, o objetivo de destruir a separação denotação-conotação, isto é, destruir a oposição objetivo/subjetivo /intersubjetivo (Ducrot, 1988, p.52).

Para Ducrot, portanto, não existe o sentido literal sobre o qual se pode pensar o sentido conotado (entre esses a metáfora). O sentido é sempre uma realização enunciativa de uma significação instrucional inscrita na estrutura da língua. Assim, resta perguntar: como pode ser vista a metáfora dentro de um quadro teórico como esse?

A noção de língua desenvolvida por Ducrot sofreu diversas alterações no decorrer dos últimos 30 anos. Nesse sentido, parece impossível estabelecer um ponto que tenha permanecido sem alterações nesse período, ou seja, a cada reformulação teórico-metodológica, Ducrot é levado a reconsiderar todo o aparato de análise que propunha para dimensioná-lo em novas bases. No entanto, essa instabilidade é apenas aparente, há um elemento que se mantém inalterado em seu trabalho: a tese de que a argumentação está inscrita na língua. Derivada desta, consolida-se uma outra tese: o componente informativo da linguagem não é evidente.

Em entrevista o próprio Ducrot afirma:

É difícil dizer que exista uma linha mestra geral ligando todo o meu trabalho de tantos anos, mas me parece que, apesar de tudo, mesmo se existem contradições entre o meu trabalho anterior (...) e o que faço atualmente (...) perduram certas 
intuições de caráter geral. Parece-me que a idéia geral que domina todo o meu trabalho é a percepção de que a língua (mais precisamente, deveríamos falar em discurso) não pode ser reduzida à função informativa e que as frases da língua comportam, semanticamente, elementos que não eqüivalem às condições de verdade (Ducrot, 1998,p.173).

Essa idéia está estreitamente ligada a uma concepção estrutural de língua, filiada aos princípios saussurianos. Em outras palavras, Ducrot permanece fiel a Saussure e em especial à crença de que a língua contém, enquanto uma estrutura relacional, os elementos suficientes que possibilitam ao lingüista uma descrição em termos de regras pertencentes a um sistema. É verdade que isso adquire novo sentido no quadro pensado por Ducrot: trata-se, fundamentalmente, da lógica interna da língua que, se compreendida, possibilita o estudo da argumentação constitutiva da língua.

O componente semântico da língua passa a ter outro estatuto porque prescinde da noção de literalidade, ou seja, se a língua é uma estrutura que comporta as relações argumentativas instanciadas enunciativamente, então não há um sentido "a priori" a partir do qual o sentido se daria, mas apenas uma lógica (derivada da língua, de cunho instrucional, e não superposta a ela), que indica as possibilidades de sua realização em um dado contexto.

A recusa do sentido literal se encontra, em Ducrot, no fato de que é a partir das palavras escritas ou pronunciadas que a enunciação e seu contexto devem ser caracterizados. As palavras dizem o que é preciso procurar para constituir o quadro no qual o discurso deverá ser interpretado. Esse quadro não preexiste à palavra enquadrada no contexto. Então, negando-se a existência de um sentido mínimo, porque as palavras indicam antes de mais nada como construir seu contexto, o estudo do contexto passa a ser integrado ao sentido do enunciado.

Decorrente disso, a noção de significação não consiste mais em supor que as palavras tenham por função descrever a realidade com valor informativo. Rejeitar a noção de sentido literal é, pois, para Ducrot, a primeira condição imposta à semântica lingüística.

Essa recusa do sentido literal, decorrente das concepções antes apresentadas, permite, heuristicamente, construir uma teoria da metáfora desligada da tradição, ou seja, descomprometida com efeitos figurativos de caráter retórico. A metáfora passa a pertencer à língua porque é um movimento constitutivo dela. Explicando melhor: aquilo que os estudos tradicionais chamam de metáfora, isto é, a passagem do sentido denotado para o conotado nada mais é do que um dos efeitos possíveis na enunciação da língua. 
A rejeição do sentido literal em Ducrot contém a idéia de que a língua não pode ser reduzida à função informativa: ela nada diz sobre um sentido básico a partir do qual tudo deve se dar. Se é assim, a metáfora perde o lugar de tropo para ocupar um lugar estrutural. Aquilo que comumente é chamado de efeito metafórico nada mais é do que um dos efeitos de realização das estruturas da língua.

Isso justifica o fato de que Ducrot, mesmo assumindo claramente uma posição de semanticista, não discuta em nenhum momento de sua teoria a questão da metáfora. Ora, se não há mais um sentido literal sobre o qual a metáfora pode se dar, então não há motivos para tratá-la diferencialmente. As relações de sentido que a tradição entendeu como metafóricas são, na verdade, relações possíveis na estrutura da língua.

Ducrot fala de "interpretação metafórica" apenas em uma breve passagem de seu posfácio a Paul Henry (1992). Diz ele:

Explicar-se-ia desse modo a grande variedade do que chamamos habitualmente de 'sentido literal'; quando entendemos por isso, não mais (...) a significação do enunciado, mas um 'sentido primeiro' da enunciação, a partir do qual definem-se as figuras e os subentendidos: cf: a ambigüidade das exegeses 'integradoras' da Escritura, que condenam certas interpretações como 'metafóricas', mas não se privam, por outro lado, de leituras que outros julgariam bastante figuradas (Ducrot, 1992, p.236) [grifos nossos].

Em outras palavras, o "sentido primeiro" sobre o qual se daria o "sentido segundo" é apenas um dos sentidos possíveis numa instância enunciativa dada. Podemos abolir a necessidade de um "sentido primeiro" - ou literal, ou denotado-, e de um "sentido segundo" - ou derivado, ou conotado:

Eles só são primeiro e segundo no interior de um processo interpretativo dado (o que é primeiro em todos os casos é a significação, mas ela não é uma interpretação: ela consiste apenas num conjunto de instruções para uma interpretação eventual) (Ducrot, 1992, p.236)

Resta perguntar pela pertinência dessas considerações para um estudo que busca entender a metáfora na neurose e, especialmente, na psicose.

\section{DERIVAÇÕES PARA A QUESTÃO DA METÁFORA}

Em termos de finalização da reflexão teórica aqui proposta, trataremos dos deslocamentos possíveis para a abordagem da neurose e, principalmente, da psicose, tendo em vista as reflexões feitas a partir das concepções lingüísticas de Ducrot.

Com relação à psicose, a questão torna-se particularmente 
interessante. É importante antes lembrar que em Schäffer et alii (1998) sublinhávamos que a língua no psicótico é estruturalmente diferente da língua no neurótico. Chegamos a tal conclusão postulando uma falha estrutural da função simbólica do signo que dificulta a instauração de um processo de antecipação polifônica na (de)negação. Processo esse realizado nos casos de neurose. Acreditamos que essas indicações sinalizam para algumas considerações sobre a metáfora na psicose.

A falha parece repetir-se para a psicose quanto à questão da metáfora. Nesse caso, percebe-se uma ausência de amarramento semântico na instanciação enunciativa, isto é, os sentidos permanecem "à deriva" sem "pontos de parada". Em termos ducrotianos, isso seria decorrência de uma falha na constituição instrucional no discurso do psicótico.

Se a língua tem na metáfora um movimento estruturalmente constituído, a ausência de "um ponto de parada" no deslocamento do significante dificulta a articulação de sentidos possíveis em uma dada situação enunciativa. Em outras palavras, o efeito de distanciamento (estranhamento semântico) diante do discurso do psicótico tem sua origem em uma falha na organização daquilo que Ducrot chama de significação. O psicótico parece ser "surdo" às instruções da língua e ao seu agenciamento enunciativo.

Por outro lado, na neurose, a metáfora tem a configuração instrucional proposta por Ducrot, isto é, há o amarramento semântico e sua conseqüente realização enunciativa. Se a significação da frase tem apenas um caráter instrucional, então pertence à lógica interna da língua a instrução que permite a interpretação metafórica. Esse movimento constitutivo, no caso da neurose, funciona sem a "errância" sem ponto de parada (incessante) verificada na psicose.

Em suma, o aparato teórico-metodológico, desenvolvido pela semântica argumentativa, interessa à psicanálise principalmente pela concepção de língua que apresenta, descomprometida com a literalidade dos sentidos, oferecendo uma possibilidade de explicação que permite distinguir a neurose da psicose. Não se trata mais de buscar efeitos figurativos. Tanto em um caso como no outro, o que importa é o mecanismo constitutivo da língua na organização dos sentidos.

\section{BIBLIOGRAFIA}

CALLIGARIS, Contardo. Introdução a uma clínica diferencial das psicoses. Porto Alegre: Artes Médicas, 1989. 
CHEMAMA, R. e VANDERMERSCH, B. (1998). Dictionnaire de la Psychanalyse. Paris: Larousse, 1988.

CZERMAK, Marcel. Paixões do objeto: estudo psicanalítico das psicoses. - Porto Alegre : Artes Médicas, 1991.

DOR, Joël L.. Introdução à Leitura de Lacan: O Inconsciente Estruturado como Linguagem. Porto Alegre: Artes Médicas, 1989. . A-cientificidade da Psicanálise : Tomo I : A alienação da Psicanálise. Porto Alegre: Artes Médicas, 1993.

DREYFUSS, J. P. "De Jakobson à Lacan. Les mécanismes du processus primaire". In: Qu'est-ce que l'inconscient? Paris: Arcanes, 1999.

DUCROT, Oswald. Polifonia y Argumentación. Cali: Universidad del Valle, 1988.

. Argumentação e "topoi" argumentativos. In: GUIMARÃES, E. História e Sentido na Linguagem. Campinas: Pontes, 1989. . O dizer e o dito. Campinas: pontes, 1987.

_. Posfácio. In: HENRY, Paul. A ferramenta imperfeita. Campinas: Pontes, 1992.

FREUD, Sigmund. Mais além do princípio do prazer (texto de 1920). In: Obras Completas - Vol. XVIII.- Buenos Aires : Amorrortu, 1993.

. La negación (texto de 1925). In: Obras Completas - Vol. 19. Buenos Aires : Amorrortu, 1989.

. Neurose e Psicose (texto de 1923-4). In: Obras Completas - Vol. 19. Buenos Aires : Amorrortu, 1993.

. A perda da realidade na neurose e na psicose (texto de 1924). In: Obras Completas - Vol. 19.- Buenos Aires : Amorrortu, 1993.

. O mal-estar na cultura (texto de 1930). In: Obras Completas. Buenos Aires, Amorrortu, 1993.

. Palavra e verdade: na filosofia antiga e na Psicanálise. Rio de Janeiro : Zahar, 1990.

. El Chiste y su relación com lo inconciente (1905c). In: Obras completas. Bueno Aires: Amorrortu, 1988.

JAKOBSON, Roman. Lingüística e comunicação. São Paulo: Cultrix, 1995.

KAUFMANN, Pierre (org). Dicionário Enciclopédico de Psicanálise: o legado de Freud e Lacan. Rio de janeiro: Jorge Zahar Ed., 1996.

LACAN, Jacques. Escritos. Jorge Zahar: Rio de Janeiro, 1998. . O seminário - Livro 1: Os escritos técnicos de Freud. Rio de Janeiro: Zahar, 1979. . O seminário - Livro 3: As psicoses. Rio de Janeiro: Zahar, 1988.

. O seminário - Livro 5: As formações do inconsciente. Rio de Janeiro: Zahar, 1999 
LECLAIRE, Serge. As palavras do psicótico. In: Colóquio internacional sobre a problemática da psicose. Montreal, 5-8 de novembro de 1969.

MELMAN, Charles. Estrutura lacaniana das psicoses. Porto Alegre: Artes Médicas, 1991.

MOURA, Heronides Maurílio de Mello. Semântica e argumentação: diálogo com Oswald Ducrot. D.E.L.T.A., vol. 14, n. 1, 1998, p. 169183

SAUSSURE, Ferdinand. Curso de Lingüistica Geral. São Paulo: Cultrix, 1975.

SCHÄFFER, Margareth et al. O processo de construção da subjetividade: marcas lingüísticas no discurso do neurótico e do psicótico. Relatório Técnico de pesquisa-CNPq, 1998

_. Constituição da subjetividade: um estudo da negação no discurso do neurótico e do psicótico. Letras de Hoje. Porto Alegre. V.34, n² 2, junho de 1999.

SCHÄFFER, Margareth. Subjetividade e Enunciação. Educação e realidade. Porto Alegre, v.24, n.1, 1999.

. A educação e a falta: algumas questões de psicanálise e epistemologia e psicologia genética. Revista da Associação psicanalítica de Porto Alegre/APPOA. Porto Alegre, v.16, n.1, 1999. 